\title{
Luomutilojen erikoistuminen yhteistyön avulla
}

\author{
M. Lätti ${ }^{1}$, K. Koikkalainen ${ }^{2}$, M. Kuisma ${ }^{3}$, T. Lötjönen ${ }^{4}$ ja A. Nykänen ${ }^{3}$ \\ ${ }^{1}$ Työtehoseura ry., Kiljavantie 6, 05201 Rajamäki, markku.latti@,tts.fi \\ ${ }^{2}$ MTT, Taloustutkimus, Luutnantintie 13,00410 Helsinki,kauko.koikkalainen@mtt.fi \\ ${ }^{3}$ MTT, Ekologinen tutkimus, Huttulantie 1,51900Juva, miia.kuisma@mtt.fi arja.nykanen@mtt.fi \\ ${ }^{4}$ MTT, Maatalousteknologian tutkimus, Tutkimusasemantie 15,92400Ruukki, timo.lotjonen@mtt.fi
}

\section{Tiivistelmä}

Tutkimuksessa selvitetään miten luomutuotantoa harjoittavien tilojen olisi mahdollista tehostaa tuotantoaan tuottajien välisen yhteistyön avulla säilyttäen tilan tuotannossa luomutuotannon vaatima monipuolisuus tai jopa lisäten sitä. Tutkimuksessa kartoitetaan luomutilojen yhteistyön taloudellisia, teknologisia, ekologisia sekä sosiaalisia hyötyjä ja esteitä. Tilamallinnuksen tavoitteena on saada rakennettavien tuotantomallien avulla selville tilojen välisen yhteistyön vaihtoehtoja sekä osoittaa havainnollisesti eri toimintojen muuttuminen ja vaikutukset, jos yhteistyöhön ryhdytään.

Staattisella mallinnuksella, Excel-taulukkolaskentaohjelmalla, rakennettujen tilamallien avulla havainnollistettiin tuotannollisen yhteistyön vaihtoehtoja luomutuotannossa saman tuotantosuunnan sekä eri tuotantosuuntien tilojen välillä. Yksittäisten tuotantosuuntien mallien pohjalta rakennettiin varsinaiset yhteistyötilamallit. Luotuja malleja validoitiin vertaamalla niiden antamia tuloksia aiempien tilatason mallinnusten tuottamiin tuloksiin (mm. TTS:n työnkäyttölaskelmat ja ProAgrian sekä MTT Taloustutkimuksen talouslaskelmat).

Eri tuotantosuuntien välistä tuotannollista yhteistyötä on mallinnettu maidon- ja vihannestuotantotilan sekä naudanlihan- ja viljantuotantotilan välisenä. Saman tuotantosuunnan yhteistyön vaikutuksia on tarkasteltu maidontuotantotilojen välisessä yhteistyössä. Eri tuotantosuuntien välinen yhteistyö, erityisesti kasvin- ja kotieläintuotantotilojen välillä, lisää viljelykierron monipuolisuutta. Kasvinviljelytilan viherlannoituskasvustot tulevat hyödynnetyiksi karjan rehuna ja myyntikasveille vapautuu lisää tuotantoalaa, kun yhteistä nurmialaa voidaan viljelykierrossa vähentää. Ravinnetaseiden avulla tarkasteltaessa ravinteidenkäytön tehostuminen ja potentiaalisten ravinnehuuhtoumien vähentyminen on havaittavissa. Eri tuotantosuuntien välinen yhteistyö lisää kokonaistyömäärää tiloilla tuotannon kasvaessa, mutta tuotettua yksikköä kohden työnkäyttö tiloilla tehostuu.

Saman tuotantosuunnan tilojen yhteistyöllä erityisesti karjantuotannossa pystytään tekemään kustannustehokkaampia ja isompia investointeja (esim. yhteisnavetat) ja sitä kautta erikoistumaan tuotannon johonkin osa-alueeseen. Työnjako tällaisissa tapauksissa vähentää myös osakkaiden työmäärää yksin toimimiseen verrattuna ja lisää jaksamisen kannalta tärkeää vapaa-aikaa.

Yhteistyötä suunniteltaessa on keskeistä valita, mihin yhteistyöllä pyritään: mitä tuotantosuuntaa, myyntikasvimäärää tai työhuipun tasoittamista yhteistyön avulla tavoitellaan kehitettäväksi ja mihin suuntaan. Näillä valinnoilla voidaan vaikuttaa $\mathrm{mm}$. tilojen tuloihin, työmääriin, tarvittaviin investointeihin ja ravinteidenkäytön tehokkuuteen haluttuun suuntaan.

Näin kattavia luomutilamalleja ei ole aiemmin tehty eikä luomutilojen yhteistyötä ole mallinnettu juuri lainkaan. Luomutilamallien rakentamisen haasteena on viljelykierron mallintaminen ja $\mathrm{mm}$. biologisen typensidonnan arviointi. Yhteistyömallien haasteena on myös kustannusten ja tuottojen jakaminen oikeudenmukaisesti osakkaiden kesken. Tärkeintä yhteistyössä on, että osapuolet kokevat saavansa yhteistyöstä jotain hyötyä ja toiminta on näin ollen kannattavampaa kuin toimiminen yksin. Käytännössä kaikki osapuolet harvoin voivat saada samansuuruisen hyödyn yhteistyöstä.

Asiasanat: luomutuotanto, yhteistyö, erikoistuminen, viljelykierto, ravinnetase, ympäristövaikutukset, tilamalli 


\section{Johdanto}

Luomutuotanto on kasvanut viimeisen vuosikymmenen aikana voimakkaasti; sen laajuus on $6,7 \%$ Suomen peltoalasta. Luomutuotantoalat ja -tuotantomäärät lisääntyvät sekä kansallisella että kansainvälisellä tasolla ja luomumarkkinat kasvavat mm. Euroopassa ja USA:ssa keskimäärin 10-20\%:n vuosivauhtia. (Hamm ja Gronefeld 2004, Richter 2005.) Kuluttajilla olisi selvitysten mukaan halukkuutta luomutuotteiden käyttöön nykyistä runsaammin, mikäli tarjonta vastaisi määrältään ja laadultaan paremmin kysyntää (Finfood Luomu 2005). Kysyntää rajoittaa myös luomutuotteiden korkeampi hinta, mikä osin johtuu korkeammista tuotantokustannuksista tavanomaiseen tuotantoon verrattuna. Luomutuotannon tehokkuutta lisäämällä tuotantokustannuksia voidaan jonkin verran alentaa. Tällöin myös kiinnostus siirtyä tavanomaisesta tuotannosta luonnonmukaiseen tuotantoon oletettavasti lisääntyisi. Noin 5400 tavanomaisessa tuotannossa olevaa tilaa (8\% kaikista tiloista) on kiinnostunut luomutuotantoon siirtymisestä (Suomen Gallup Elintarviketieto Oy 2004).

Yksi keino luomutuotannon kannattavuuden parantamiseen ja luomutuotteiden tarjonnan lisäämiseen on niin luomutilojen välisen kuin luomu- ja tavanomaisten tilojen välisen yhteistyön lisääminen. Suomen Gallup Elintarviketieto Oy:n (2004) tekemän kyselyn mukaan luomutuottajat pitävät kasvintuotannon kannattavuuden parantamisen yhtenä keinona yhteistyön lisäämistä. Tuotantokustannusten alentamisen lisäksi eri tuotantosuuntien välisellä tuotannollisella yhteistyöllä oletetaan olevan myönteistä vaikutusta ympäristöön ravinnekuormituksen vähentyessä (Lötjönen ym. 2004). Samalla tilojen satotason voidaan odottaa nousevan (Lötjönen ym. 2004, Nummela 1998).

Tässä tutkimuksessa selvitettiin miten luomutuotantoa harjoittavien tilojen olisi mahdollista tehostaa tuotantoaan säilyttäen samalla kuitenkin tilan tuotannossa luomun vaatima viljelykierron monipuolisuus. Tavoitteena oli alueellisesti tasapainoinen ja monipuolinen tuotanto, mikä on kestävän tuotannon edellytys. Tutkimuksessa kartoitettiin luomutilojen yhteistyön taloudellisia, ekologisia sekä sosiaalisia hyötyjä ja esteitä. Lisäksi mallilaskelmien avulla selvitettiin yhteistyön taloudellisia, työnkäytöllisiä ja ekologisia vaikutuksia tilojen toimintaan.

\section{Aineisto ja menetelmät}

Tutkimus koostui kirjallisuustutkimuksesta, tilatutkimuksista ja yhteistyötilamallinnuksesta. Tilatutkimusosassa tutustuttiin viiteen yhteistyötä tekevään tilarenkaaseen, joiden yhteistyön toimivuutta arvioitiin mm. ravinnetase- ja talouslaskelmien avulla. Kirjallisuustutkimuksen ja tilavierailujen tuloksia ei esitetä tässä. Tulokset julkaistaan kokonaisuudessaan keväällä 2006 ilmestyvässä Työtehoseuran julkaisussa.

Yhteistyötilamallinnuksen tavoitteena oli selvittää luomutilojen yhteistyön vaikutuksia tuotantoon, ympäristöön, työntarpeeseen ja myyntituotteiden tuotantokustannuksiin. Staattinen mallinnustapa valittiin, koska haluttiin tuoda esille yhteistyön vaikutukset koko vuoden tuloksiin eikä hetkittäisiin arvoihin. Mallit rakennettiin Excel-taulukkolaskentaohjelmalla. Mallinnuksen aluksi rakennettiin kolmen kokoluokan luomuperusmallit tuotantosuunnittain (maidon-, naudanlihan-, viljan- ja vihannestuotanto). Perusmalleista muodostettiin luomuyhteistyötilamallit siten, että mallinnettavaksi tuli sekä saman tuotantosuunnan tilojen yhteistyötä että kahden-kolmen eri tuotantosuunnan tilojen yhteistyötä taulukon 1 mukaisesti.

Taulukko 1. Rakennetut yksittäiset tilamallit ja niistä muodostetut yhteistyötilamallit.

\begin{tabular}{|c|c|c|c|c|c|c|}
\hline \multirow[b]{2}{*}{ 1. Yksittäiset tilamallit } & \multicolumn{2}{|c|}{ Kokoluokka 1} & \multicolumn{2}{|c|}{ Kokoluokka 2} & \multicolumn{2}{|c|}{ Kokoluokka 3} \\
\hline & $h a$ & eläimiä & ha & eläimiä & $h a$ & eläimiä \\
\hline Maidontuotanto & 70 & 30 lehmää & 140 & 60 lehmää & 700 & 300 lehmää \\
\hline Lihantuotanto & 45 & 30 emoa & 90 & 60 emoa & 450 & 300 emoa \\
\hline Viljantuotanto & $80 *$ & & $200 *$ & & $1000^{*}$ & \\
\hline Vihannestuotanto & $20 *$ & & $40 *$ & & $120 *$ & \\
\hline 2. Yhteistyötilamallit & $h a$ & eläimiä & & & & \\
\hline a) Maidontuotanto1 \& Vihannestuotanto1 & 90 & 30 lehmää & & & & \\
\hline b) Lihantuotanto1 \& Viljantuotanto1 & 125 & 58 emoa & & & & \\
\hline c) $3 \times$ Maidontuotanto 1 & 210 & 180 lehmää & & & & \\
\hline d) Vihannestuotanto1 \& Viljantuotanto1 \& Lihantuotanto1 & 145 & 30 emoa & & & & \\
\hline
\end{tabular}


Tilamalleista rajattiin pois mm. säätekijöiden ja maalajien vaikutus satoihin ja ravinnehuuhtoumiin, tilojen tilussuhteet, investointituet sekä verotus eli näitä tekijöitä ei mallinnettu. Esimerkiksi tilussuhteista oletettiin, että suuren tilan peltolohkot ovat keskimäärin kauempana talouskeskuksesta kuin pienen tilan (Myyrä 2003). Sen sijaan mm. viljelykierrot, työnkäyttö, pelto- ja kotieläintuet, tämänhetkinen hintataso sekä ravinnevirrat yritettiin mallintaa mahdollisimman tarkasti.

Tilamallien työnkäyttö määritettiin Työtehoseuran kokoamista työnormeista työmenetelmän ja kaluston kokoluokan mukaan. Mallien kokonaistyömääriä laskettaessa suunnittelu- ja johtotöiden määräksi oletettiin pienimmissä malleissa $5 \%$ kokonaistyönmenekistä, keskimmäisissä malleissa 10 $\%$ ja suurimmissa malleissa $20 \%$. Yhteistyön onnistumisen mittareina käytettiin mm. ravinnetaseita, työmäärää ja talousmittareita. Malleja validoitiin vertaamalla niiden antamia tuloksia aiempien tilatason mallinnusten tuottamiin tuloksiin (TTS:n työnkäyttölaskelmat, Sirkula-ravinnetaseohjelma, ProAgrian ja MTT Taloustutkimuksen talouslaskelmat).

Tilamallien sato- ja tuotosoletuksina käytettiin taulukon 2 mukaisia arvoja. Sato- ja tuotostasojen muuttumisen vaikutusta lopputuloksiin eli mallien herkkyyttä tullaan vielä testaamaan. Luomutuotannon sadoista ja tuotoksista ei edelleenkään ole olemassa kattavia tilastoja, vaan arvot on kerätty useista eri lähteistä.

Taulukko 2. Malleissa käytetyt sato- ja tuotosoletukset (Klemola 1996, ProAgria 2005, KTTK 2004).

\begin{tabular}{|c|c|c|c|c|}
\hline & $\mathrm{kg} / \mathrm{ha}$ & ry/ha & & \\
\hline Rehuvilja & 2250 & 2050 & Maitoa & $7500 \mathrm{~kg} / \mathrm{lehmä} / \mathrm{v}$ \\
\hline Säilörehunurmi & 17000 & 3780 & Lihaa (hieho) & $900 \mathrm{~g} / \mathrm{vrk}$ \\
\hline Laidunnurmi & 14700 & 2400 & Lihaa (sonni) & $1500 \mathrm{~g} / \mathrm{vrk}$ \\
\hline Leipävilja & 2250 & & & \\
\hline Herne-kaura & 2250 & & & \\
\hline Sipuli (brutto) & 14400 & & & \\
\hline
\end{tabular}

\section{Tulokset ja tulosten tarkastelu}

Yhteistyötilamallinnus on vielä osittain kesken, joten tässä käsittelemme yhteistyötilamalleista vain taulukossa 1 mainittuja malleja a ja b. Luomukasvinviljely- ja luomukotieläintilan yhteistyössä kannattaa pyrkiä hyödyntämään kasvinviljelytilan viherkesanto karjan rehuna ja karjatilalta ylitse jäävä lanta kasvinviljelytilan lannoitteena. Ainakin periaatteessa tällainen yhteistyö mahdollistaa myytävien tuotteiden määrän lisäämisen.

\section{a) Maito- ja vihannestilan yhteistyö}

Maito- ja vihannestilan yhteistyössä voitaisiin keskittyä lehmämäärän, sipulipinta-alan tai molempien lisäämiseen. Sipulipinta-alan lisääminen onnistuu varastoa laajentamalla, mikä katsottiin tässä olevan järkevämpää kuin navetan ja rehuvarastojen laajentaminen sekä lisäkiintiöiden hankkiminen. Yhteinen viljelykierto muodostettiin muuttamalla tilojen aiemmat nelivuotiset viljelykierrot viisivuotiseksi (vilja + ns - apilanurmi - apilanurmi - apilanurmi/pyydyskasvi - sipuli/vilja). Uudessa viljelykierrossa sipuliala pystyttiin lähes kaksinkertaistamaan. Periaatteessa sipulialaa voitaisiin kasvattaa vieläkin muutamalla hehtaarilla ja silti lypsylehmien nurmen ja viljan tarve voitaisiin täyttää kotoisin rehuin.

Ravinnetalous. Maitotilan toimiessa yksin lietelantaa riittää $39 \mathrm{~m}^{3}$ viljahehtaareille, josta tulee liukoista typpeä noin $75 \mathrm{~kg} / \mathrm{ha}$. Tämä saattaa olla yhdessä nurmen biologisen typensidonnan (kaikki lohkot $50 \mathrm{~kg} / \mathrm{ha}$ ) kanssa suojaviljalle jopa liikaa. Yhteistyötilamallissa sipuli- ja vilja-aloille on lietelantaa käytettävissä $19 \mathrm{~m}^{3} /$ ha (liukoista typpeä noin $36 \mathrm{~kg} / \mathrm{ha}$ ) ja biologista typensidontatyppeä tulee kaikille lohkoille $36 \mathrm{~kg} / \mathrm{ha}$. Mallilaskelmissa on oletettu, että maitotilan kasvien sadot säilyvät samoina lietteen määrän vähenemisestä huolimatta. Maitotilan sadot saattavat kuitenkin laskea jonkin verran, mutta vihannestilan satojen pitäisi parantua, koska aiemmin karjanlantaa ei ollut käytettävissä (biologista typensidontatyppeä tuli vihannestilalle yksin toimittaessa $40 \mathrm{~kg} / \mathrm{ha}$ ). Satotasoja ei vihannestilankaan osalta ole kuitenkaan yhteistyötilamallissa korotettu.

Tilamallien ravinnetaloutta tarkasteltiin ravinnetaselaskennan avulla. Ravinnetaseista laskettiin:

* Porttitase $=$ Tilalta luovutetut tuotteet $/$ Tilalle hankitut tuotantopanokset

* Peltotase $=$ Pellolta korjattu sato / Peltoon sijoitetut tuotantopanokset

* Karjatase $=$ Myydyt eläintuotteet / Eläimille syötetty rehu 
* Primääriravinnetase $=$ Pellolta korjattu sato $/$ Tilalle hankitut primääriravinteet $(\text { Seuri 2002 })^{l}$

* Kierrätyskerroin $=($ Tilalle hankitut primääriravinteet + Tilan kiertävät sekundääriravinteet $) /$ Tilalle hankitut primääriravinteet (Seuri 2002) (ks. Alaviite ${ }^{l}$ )

Seurin (2002) kasvinravinteiden jako tilan ulkopuolisiin ja tilalla kiertäviin mahdollistaa eri tuotantosuuntien yhteismitallisen tarkastelun kasvintuotannon osalta. Karjantuotannosta aiheutuu väistämättä enemmän ravinnetappioita kuin kasvintuotannosta, joten portti- ja peltotaseet eivät mahdollista näiden eri tuotantosuuntien todellista vertaamista keskenään. Primääriravinnetaseella eri tuotantosuunnissa harjoitettua kasvintuotantoa voidaan verrata keskenään.

Taulukossa 3 on esitetty mallinnettujen lypsykarjatilan ja vihannestilan sekä tilojen yhteistyössä muodostaman tilakokonaisuuden typpi- ja fosforitaseet. Perusmallit (Maito ja Vihannes) havainnollistavat erikoistuneiden karjan- ja kasvintuotantotilojen välillä vallitsevaa eroa. Karjatilojen porttitase on pääsääntöisesti heikompi mm. eläintuotteissa poistuvien ravinnemäärien vähäisyyden vuoksi. Vihannestilan pelto- ja primääriravinnetaseet jäävät heikoiksi, koska suurella osalla peltopinta-alaa kasvaa typensidontakasvustoja eikä niistä voida korjata myyntisatoa.

Taulukko 3. Mallinnettujen itsenäisten lypsykarja- ja vihannestilojen sekä tilojen yhteistyössä muodostaman tilakokonaisuuden ravinnetaseet (typpi ja fosfori) suhteellisina arvoina ja ravinteiden ylijäämät (kg/ha).

\begin{tabular}{llllllll}
\hline & & \multicolumn{2}{c}{ Maitomalli } & \multicolumn{2}{c}{ Vihannesmalli } & \multicolumn{2}{c}{ MaitoSipuliMalli } \\
& & \multicolumn{2}{c}{ ylijäämä, $\mathrm{kg} / \mathrm{ha}$} & \multicolumn{2}{c}{ ylijäämä, $\mathrm{kg} / \mathrm{ha}$} & \multicolumn{2}{c}{ ylijäämä, $\mathrm{kg} / \mathrm{ha}$} \\
\hline TYPPI & Porttitase & 0,27 & 50 & 0,32 & 35 & 0,36 & 33 \\
& Peltotase & 0,75 & 27 & 0,35 & 33 & 0,73 & 22 \\
& Karjatase & 0,21 & & & & 0,21 & \\
& Primääriravinnetase & 1,25 & & 0,35 & & 1,26 & \\
& Kierrätyskerroin & 1,67 & & & & 1,71 & \\
\hline FOSFORI & Porttitase & 0,93 & 0,26 & 2,55 & $-1,74$ & 0,98 & 0,09 \\
& Peltotase & 1,00 & $-0,03$ & 2,76 & $-1,98$ & 0,92 & 0,72 \\
& Karjatase & 0,27 & & & & 0,27 & \\
& Primääriravinnetase & 3,48 & & 2,76 & & 2,76 & \\
& Kierrätyskerroin & 3,48 & & & & 3,00 & \\
\hline
\end{tabular}

MaitoSipuli-yhteistyötilamallin ravinteidenkäytön tehostuminen johtuu resurssien tehokkaammasta hyödyntämisestä: aiempi kasvinviljelytilan viherlannoitusala tulee hyödynnettyä karjatilan rehunurmena. Karjantuotanto ei lisäänny vaan mallissa lisätään erityisesti sipuli-, mutta myös nurmi- ja viljaalaa. Ravinteidenkäyttö tehostuu yhteistyömallissa selkeästi verrattuna erikoistuneeseen kasvinviljelytilaan (primääriravinnetase ja kierrätyskerroin). Karjatilan aiempaan ravinteidenkäyttöön verrattuna yhteistyö ei tuo merkittävää parannusta. Yhteistyömalli onkin selkeästi erikoistuneen kasvintuotannon ravinteidenkäyttöä tehostava. Tuotannon kokonaiskuormituspotentiaali laskee typen osalta kumpaankin alkuperäiseen tilaan verrattuna (peltotaseen ylijäämä).

Myyntituotteet. Sato-oletusten mukaan yhteistyön tuloksena voidaan tuottaa 80 \% (48 $000 \mathrm{~kg}$ nettosatoa) enemmän sipulia verrattuna yksin toimimiseen. Lypsykarjalle ostettiin viljaa ennen yhteistyötä noin $12000 \mathrm{~kg} / \mathrm{v}$, nyt viljaa liikenee myyntiin $7500 \mathrm{~kg} / \mathrm{v}$. Maitoa ja lihaa tuotetaan samat määrät kuin ennen yhteistyötä. Sipulin viljelykierto on nyt vuoden pidempi kuin yksin toimittaessa, mikä saattaa vähentää tuholais- ja tautiriskiä. Tämäntyyppisen yhteistyön tuotannolliset edut ovat siis varsin merkittäviä.

\footnotetext{
${ }^{1}$ Seurin (2002) kasvintuotannossa käytettyjen ravinnepanosten jako primääri- ja sekundääriravinteisiin perustuu ravinteiden alkuperään. Primääriravinteet hankitaan tilan (systeemin) ulkopuolelta kasvintuotantoon: biologisen typensidonnan typpi, laskeuman mukana tulevat ravinteet, ostosiemenet, ostokuivikkeet ja ostorehuista lantaan päätyvät ravinteet. Sekundääriravinteet ovat tilalla kiertäviä ravinteita, omasta rehusta lantaan päätyviä ravinteita. Primääriravinnetase kuvaa siten ulkopuolelta kasvintuotantoon hankittujen ravinnepanosten suhdetta tilalla korjattuun satoon. Yli 1,0 olevan primääriravinnetase kuvaa jo tilalla tapahtuvaa kierrätystä, kun yhdellä ulkoa tuodulla ravinneyksiköllä saadaan yli yksi ravinneyksikköä korjattua satoa. Kierrätyskerroin kuvaa sekundääriravinteiden, tilan sisällä kiertävien ravinteiden, määrää suhteessa systeemin kokonaisravinnemäärään.
} 
Työnkäyttö. Kuvassa 1 on esitetty mallinnettujen lypsykarjatilan (70 ha, 30 lehmää) ja vihannestilan (20 ha, josta sipulia 5 ha) työnkäyttö tilojen toimiessa yksin ja tilojen tehdessä yhteistyötä. Maidontuotantotilalla vuotuinen työnkäyttö hieman pienenee $(3315 \mathrm{~h} / \mathrm{v}>3210 \mathrm{~h} / \mathrm{v})$, kun perusmuokkaus ja viljanviljelytyöt (pois lukien viljan korjuu) siirtyvät vihannestilan tehtäväksi. Karjahoitotöiden määrässä ei tapahdu muutosta karjamäärän ja tuotantoteknologian pysyessä ennallaan. Vihannestilalla vuotuinen työmäärä kasvaa sipulin viljelypinta-alan lähes kaksinkertaistuessa ( 5 ha $>9$ ha) yli kolminkertaiseksi $(217 \mathrm{~h} / \mathrm{v}>693 \mathrm{~h} / \mathrm{v})$. Osaltaan tähän vaikuttaa myös ennen urakointina teetetyn sipulin karhelta noston tekeminen omalla kalustolla. Sipulin viljelypinta-alan lisäyksellä ja viljanviljelytöillä yrittäjää saadaan työllistettyä paremmin verrattuna tilanteeseen ennen yhteistyötä. Maito- ja vihannestilan yhteistyössä tilojen sesonkityöt ajoittuvat osin eri aikaan, joten yrittäjät voivat olla toistensa apuna esimerkiksi kylvö- ja istutus- sekä sadonkorjuutöissä. Yhteistyössä tehtävien työvaiheiden vaikutusten on oletettu kumoavan toisensa (esim. sipulinistutus ja säilörehunkorjuu), joten niillä ei ole vaikutusta tilojen kokonaistyöaikaan.

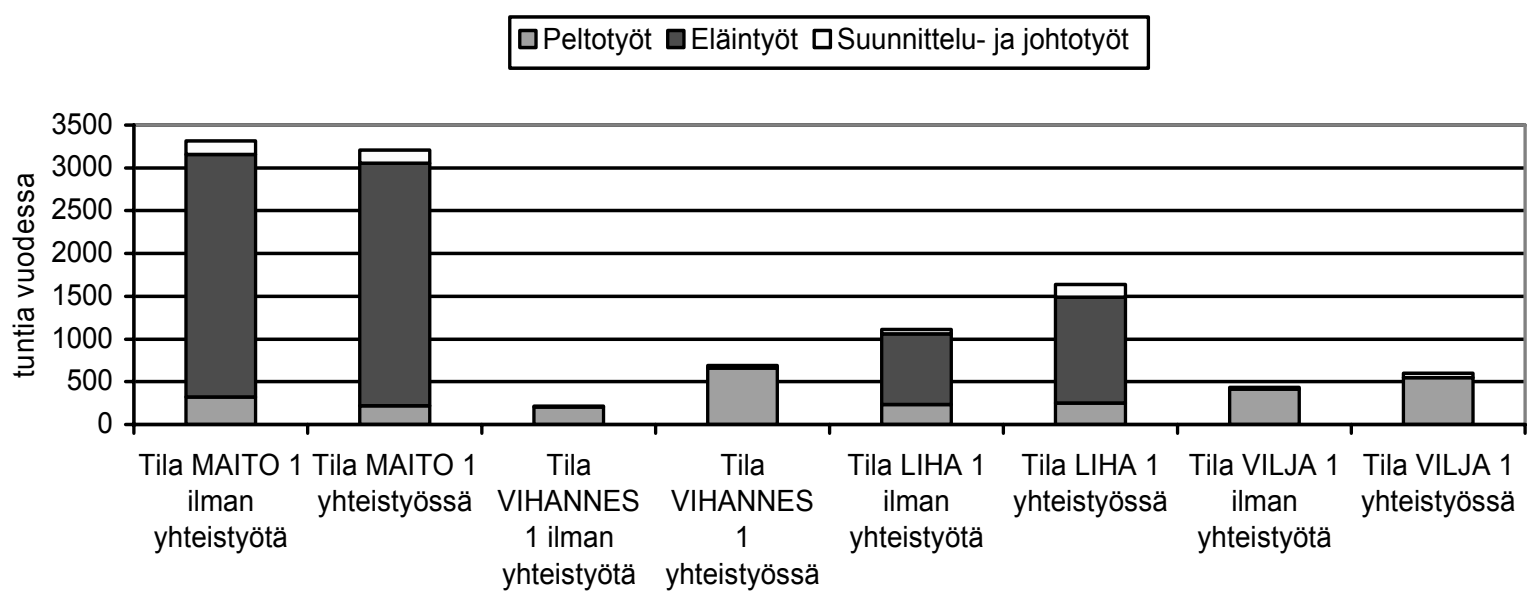

Kuva 1. Työnkäyttö maito- ja vihannestilalla sekä liha- ja viljatilalla ilman yhteistyötä ja yhteistyössä.

Rakennukset, koneet ja talous. Sipulivarastoa joudutaan laajentamaan noin 15000 eurolla, mikä ei ole kovin suuri investointi. Tilojen konekanta on sen verran ylimitoitettu, että suurin osa tiloilla olevista samoista koneista voidaan myydä pois. Esimerkiksi maito- ja sipulitilalla selvitään kolmella traktorilla neljän sijasta. Poismyytävien koneiden markkina-arvoksi on arvioitu puolet uuden koneen hankintahinnasta. Näin laskettuna koneiden myynnistä kertyy yhteensä 24000 euron tulot. Samalla pitää kuitenkin huomata, että jäljelle jäävien koneiden käyttö kasvaa ja huolto- ja korjaustarve voivat lisääntyä. Samoin ajallisuuskustannukset voivat kasvaa kriittisten koneiden osalta. Maito- ja sipulitilan työhuiput ajoittuvat paljolti limittäin, joten suuria ajallisuuskustannuksia ei pitäisi näillä pinta-aloilla tulla. Nurmenviljely ja sipulinviljely vaativat erikoiskoneita, joten säästö konekustannuksessa ei ole yhtä suuri kuin mitä se olisi saman tuotantosuunnan tiloilla.

Taulukko 4. Talouden tunnuslukuja mallinnetuilla tiloilla yksin toimien ja yhteistyössä. Nettovoitosta ei ole vielä vähennetty veroja.

\begin{tabular}{lllllllll}
\hline & Maito1 & Sipuli1 & Liha1 & Vilja1 & MaitoSipuli & MaitoSipuli & LihaVilja & LihaVilja \\
\hline Pinta-ala, ha & 70 & 5 & 45 & 80 & 72 & 9 & $\mathbf{5 0}$ & $\mathbf{7 5}$ \\
Tuotantomäärä, kg tai 1 & 216000 & 60000 & 5025 & 90000 & 216000 & 108000 & $\mathbf{9 7 1 5}$ & $\mathbf{1 1 2} \mathbf{5 0 0}$ \\
Tarvikekustannus, $€ / \mathrm{kg}$ & 0,10 & 0,14 & 3,15 & 0,11 & 0,08 & 0,16 & $\mathbf{2 , 4 9}$ & $\mathbf{0 , 1 1}$ \\
Työkustannus, $\boldsymbol{€} / \mathbf{k g}$ & $\mathbf{0 , 1 9}$ & $\mathbf{0 , 0 9}$ & $\mathbf{2 , 7 1}$ & $\mathbf{0 , 0 6}$ & $\mathbf{0 , 1 9}$ & $\mathbf{0 , 0 6}$ & $\mathbf{2 , 0 6}$ & $\mathbf{0 , 0 7}$ \\
Yleiskustannus, $€ / \mathrm{kg}$ & 0,03 & 0,02 & 0,59 & 0,02 & 0,03 & 0,02 & $\mathbf{0 , 4 6}$ & $\mathbf{0 , 0 2}$ \\
Omaisuuskustannus, $€ / \mathrm{kg}$ & 0,19 & 0,26 & 6,59 & 0,26 & 0,20 & 0,22 & $\mathbf{4 , 7 5}$ & $\mathbf{0 , 2 1}$ \\
Tuotantokustannus, $€ /$ kg & $\mathbf{0 , 4 6}$ & $\mathbf{0 , 5 1}$ & $\mathbf{1 3 , 0 3}$ & $\mathbf{0 , 4 5}$ & $\mathbf{0 , 5 0}$ & $\mathbf{0 , 4 6}$ & $\mathbf{9 , 7 5}$ & $\mathbf{0 , 4 1}$ \\
Nettovoitto, $€ / \mathrm{kg}$ & 0,26 & 0,11 & 1,30 & 0,21 & 0,24 & 0,16 & $\mathbf{3 , 6 5}$ & $\mathbf{0 , 1 8}$ \\
\hline
\end{tabular}


MaitoSipuli-yhteistyötilamallissa suuremmat taloudelliset hyödyt tulevat sipuliosapuolelle johtuen sipulintuotannon lisäämisestä. Sipulikilon tuotantokustannus alenee aikaisempaan yksin toimimiseen verrattuna yli $10 \%$. Suurimmat tuoteyksikköä kohti lasketut säästöt tulevat työkustannuksen ja omaisuuskustannuksen pienenemisestä (Taulukko 4). Maito-osapuolen laskennallinen tuotantokustannus jopa hieman kasvaa yhteistoiminnan seurauksena. Tämä johtuu mm. viljankorjuukustannusten siirtymisestä maitotilalle. Yhteistoiminnan tulosta tasattaessa tuleekin kiinnittää huomiota siihen, että molemmat toiminnan osapuolet saavat oikeudenmukaisen korvauksen yhteistyöstä.

\section{b) Liha- ja viljatilan yhteistyö}

Liha- ja viljatilan yhteistyössä voitaisiin keskittyä karjamäärän, viljapinta-alan tai molempien lisäämiseen. Tilamallitarkastelussa päädyttiin karjamäärän lisäämiseen, koska luomunaudanlihan markkinat näyttävät lupaavilta ja emolehmätuotannolle osoitettuja tukia on saatavilla. Tosin rakennuksiin joudutaan investoimaan enemmän, kuin mitä olisi jouduttu investoimaan viljantuotantoon keskittymällä. Yhteinen viljelykierto muodostettiin muuttamalla tilojen aiemmat neli- ja kolmivuotiset viljelykierrot viisivuotiseksi (vilja + ns - apilanurmi - apilanurmi - vilja/rypsi - vilja + palkovilja).

Ravinnetalous. Kuivikelantaa riittää yhteistyötilamallissa $18 \mathrm{~m}^{3} /$ ha (kahdelle viljavuodelle kolmesta), kun sitä yksin toimiessa riitti emolehmätilan suojaviljalle $31 \mathrm{~m}^{3} /$ ha. Biologisen typensidontatypen määrä yhteistyötilamallissa on $41 \mathrm{~kg}$ kaikille peltohehtaareille, kun alkuperäisessä Lihamallissa se oli $55 \mathrm{~kg} / \mathrm{ha}$ ja Viljamallissa $60 \mathrm{~kg} / \mathrm{ha}$. Taulukossa 5 on esitetty mallinnettujen nautakarjatilan ja viljatilan sekä tilojen yhteistyössä muodostaman tilakokonaisuuden typpi- ja fosforitaseet. Perusmallien (Lihamalli ja Viljamalli) erot ovat vastaavia kuin edellä kuvatut Maito- ja Vihannesmallien erot.

Taulukko 5. Mallinnettujen itsenäisten nautakarja- ja viljatilojen sekä tilojen yhteistyössä muodostaman tilakokonaisuuden ravinnetaseet (typpi ja fosfori) suhteellisina arvoina ja ravinteiden ylijäämät ( $\mathrm{kg} / \mathrm{ha}$ ).

\begin{tabular}{|c|c|c|c|c|c|c|c|}
\hline & & Lihar & $m \ddot{a} k g / h a$ & Vilja & imä $k g / h a$ & Liha & $\begin{array}{l}\text { Malli } \\
\text { imä, } k g / h a\end{array}$ \\
\hline TYPPI & Porttitase & 0,08 & 73 & 0,33 & 45 & 0,32 & 32 \\
\hline & Peltotase & 0,77 & 25 & 0,32 & 46 & 0,98 & 1,3 \\
\hline & Karjatase & 0,08 & & & & 0,09 & \\
\hline & Primääriravinnetase & 1,11 & & 0,32 & & 1,31 & \\
\hline & Kierrätyskerroin & 1,45 & & & & 1,33 & \\
\hline FOSFORI & Porttitase & 0,29 & 4,4 & 17 & $-3,4$ & 1,50 & $-1,0$ \\
\hline & Peltotase & 0,79 & 3,0 & 8,3 & $-3,2$ & 1,21 & $-1,8$ \\
\hline & Karjatase & 0,12 & & & & 0,14 & \\
\hline & Primääriravinnetase & 2,03 & & 8,3 & & 3,65 & \\
\hline & Kierrätyskerroin & 2,56 & & & & 3,03 & \\
\hline
\end{tabular}

LihaVilja-yhteistyömallin ravinteidenkäytön tehostuminen johtuu MaitoSipuli-yhteistyömallin tapaan resurssien tehokkaammasta hyödyntämisestä: aiempi kasvinviljelytilan viherlannoitusala tulee hyödynnettyä karjatilan rehunurmena. Yhteistyön seurauksena karjamäärää lisätään, jolloin laskennallisen typpipanoksen voi olettaa mahdollistavan satotasojen säilymisen ennallaan. Myös vilja-ala lisääntyy. Typpikuormituspotentiaali alenee yhteistyömallissa selvästi erikoistuneisiin tiloihin nähden. Tilojen ulkopuolisten ravinteiden hyödyntäminen paranee yhteistyömallissa yksin toimimiseen nähden (primääriravinnetase). Kierrätyskerroin kuitenkin alenee verrattaessa sitä Lihamallin vastaavaan, koska LihaViljaMallissa ulkoa tulevien ravinteiden määrä lisääntyy ( $\mathrm{mm}$. biologinen typensidonta) enemmän kuin kiertävien ravinteiden määrä (karjanlanta).

Myyntituotteet. Yhteistyön seurauksena rehua riittää liki kaksinkertaiselle karjamäärälle aiempaan nähden. Lihaa voidaan tuottaa yli 90 \% (4 690 teuraskiloa) enemmän kuin aiemmin. Eläinten tarvitsema vilja ja kuivikeolki saadaan nyt yhteistyön avulla, kun ne aiemmin jouduttiin ostamaan. Myytävän viljan/palkoviljan määrä kasvaa muutamalla tuhannella kilolla. 
Työnkäyttö. Kuvassa 1 on esitetty mallinnettujen nautakarjatilan (45 ha, 30 emolehmää) ja viljatilan (80 ha) työnkäyttö tilojen toimiessa yksin ja tilojen tehdessä yhteistyötä. Emolehmätila hyötyy viljatilan kanssa tehtävästä yhteistyöstä hyödynnettävän nurmialan (aiemmin viljatilan viherlannoitusnurmi) huomattavalla kasvulla. Emolehmätilalla on siten mahdollista kasvattaa lähes kaksinkertainen määrä eläimiä (30 emoa > 58 emoa). Tuotannon lisääminen vaikuttaa luonnollisesti myös työn kokonaismäärään, joka kasvaa reilusta 1100 tunnista reiluun 1600 tuntiin vuodessa. Samalla tuotannon lisäämisen kanssa työnkäyttö kuitenkin tehostuu. Työmenetelmät pysyvät tilalla muuten samoina, mutta ruokinnassa siirrytään erillisruokinnasta aperuokintaan. Lisäksi viljanviljelytyöt tekee yhteistyöviljatila. Kuvatussa yhteistyömallissa lihakarjayrittäjä pystyy hoitamaan tilan päivittäiset työt vielä omalla työpanoksellaan läpi vuoden huolimatta tuotannon kaksinkertaistumisesta. Viljatilan työnmenekki ilman yhteistyötä on reilu $400 \mathrm{~h} / \mathrm{v}$. Yhteistyössä viljatila hoitaa kaiken tilojen viljanviljelyyn liittyvän työn, jolloin työnmenekki kasvaa 600 tuntiin vuodessa. Viljatilalla olemassa oleva konekapasiteetti riittää kasvaneen viljelypinta-alan viljelyyn, joten se tulee samalla paremmin hyödynnetyksi.

Rakennukset, koneet ja talous. Kasvanut karjamäärä vaatii noin 104000 euron investoinnin kylmäpihaton, varastojen ja lantalan laajennukseen. Viljavarastoa ei tarvitse laajentaa, koska käytettävissä on yhteistyökumppanin kuivurin varastosiilot. Karjan ruokinnassa siirrytään aperuokintaan ja lannanlevityksessä tehokkaampaan kokoluokkaan, mikä edellyttää investointeja näihin koneisiin. Yksi ylimääräinen traktori ja eräitä päällekkäisiä viljanviljelykoneita voidaan myydä pois. Kokonaisuutena konekannan arvo kasvaa 4000 eurolla karjatilalle tehtyjen koneinvestointien seurauksena.

LihaVilja-yhteistyömallissa molempien osapuolten tuotantokustannukset alenevat, joskin lihantuotanto-osapuolen hyöty on suurempi. Laskennallinen tuotekohtainen tuotantokustannus alenee lihantuotannossa $25 \%$ ja viljantuotannossa hieman alle $10 \%$. Lihantuotannossa yhteistoiminta alentaa kaikkia kustannuseriä ja suurin laskennallinen säästö tulee kiinteissä kustannuksissa (Taulukko 4). Myös viljantuotannossa kiinteissä kustannuksissa saavutettu säästö on merkittävin.

\section{Johtopäätökset}

Luomutuotannon vaatimuksiin kuuluu viljelykierron kautta tuotannon monipuolisuus, joka saattaa olla ristiriidassa kustannustehokkaan tuotannon kanssa. Tilojen välisellä yhteistyöllä riittävä monipuolisuus voidaan turvata samanaikaisesti tehokkaan tuotannon kanssa. Luomukasvintuotannossa osa tilan peltoalasta on pidettävä typpeä sitovina kasvustoina lannoitusvaikutuksen sekä kasvitautien ja rikkakasvien torjumiseksi. Luomukasvinviljelytilan ja -karjatilan yhteistyö yhteisen viljelykierron muodossa lisää tilojen mahdollisuuksia hyödyntää erityisesti nurmialaa tehokkaammin, jolloin myös valittuja tuotantomääriä pystytään kasvattamaan. Tästä seuraa kuitenkin kokonaistyömäärän kasvaminen tiloilla, mutta tuotettua yksikköä kohden työnkäyttö tiloilla tehostuu.

Saman tuotantosuunnan tilojen (lähinnä karjatilat) yhteistyöllä pystytään tekemään kustannustehokkaampia ja isompia investointeja (esim. yhteisnavetat) ja sitä kautta erikoistumaan tuotannon johonkin osa-alueeseen ja kehittämään tätä osa-aluetta eteenpäin. Työnjako tällaisissa tapauksissa vähentää myös osakkaiden työmäärää yksin toimimiseen verrattuna ja lisää jaksamisen kannalta tärkeää vapaa-aikaa.

Näin kattavia luomutilamalleja ei ole aiemmin tehty eikä luomutilojen yhteistyötä ole mallinnettu juuri lainkaan. Luomutilamallien rakentamisen haasteena on viljelykierron mallintaminen ja $\mathrm{mm}$. biologisen typensidonnan arviointi. Yhteistyömallien haasteena on myös kustannusten ja tuottojen jakaminen oikeudenmukaisesti osakkaiden kesken.

Onnistuakseen yhteistyö vaatii etukäteissuunnittelua, joustavuutta ja luottamusta yhteistyökumppaneiden välillä. Tärkeintä yhteistyössä on, että osapuolet saavat yhteistyöstä jotain hyötyä ja toiminta on näin ollen kannattavampaa kuin toimiminen yksin; käytännössä kaikki osapuolet eivät voi saada aina samanlaista ja samansuuruista hyötyä.

\section{Kirjallisuus}

Finfood Luomu 2005. Kuluttajien asenteet luomuun myönteiset. Saatavissa: http://www.finfood.fi/finfood/luomu.nsf/0/92CBB681E216E0B0C22570AB0023C130?OpenDocument\&cat $1=$ Ajankohtaista\&cat $2=$ Tiedotteet

Hamm, U. \& Gronefeld, F. 2004. The European Market for Organic Food: Revised and Updated Analysis. OMIaRD. The University of Wales, Aberystwyth, United Kingdom. 165 p. 
Klemola, E. 1996. Luomutuotannon työnmenekkiin vaikuttavat tekijät. Työtehoseuran maataloustiedote 1/1996 (467). $8 \mathrm{~s}$.

KTTK, 2004. Luonnonmukainen maatalous 2003, Tilastoja. Kasvintuotannon tarkastuskeskus, 53 s.

Lötjönen, T., Muuttomaa, E., Koikkalainen, K., Seuri, P. \& Klemola, E. 2004. Laajamittaisen luomutuotannon teknologia - taloudellinen toteutettavuus ja ekologinen kestävyys. Maa- ja elintarviketalous 44, $131 \mathrm{~s} .+$ 4 liitettä. Saatavissa: http://www.mtt.fi/met/pdf/met44.pdf

Myyrä, S. 2003. Laajentavien tilojen tilusrakenne. Julkaisussa: Enroth, A., Österman, P. \& Teräväinen, H. (toim.) 2003. Laajentavien tilojen haasteet. Tieto tuottamaan 104.

Nummela, P. 1998. Tuotannollisen yhteistyön vaikutus maatilan kannattavuuteen. Maatalouden taloudellinen tutkimuslaitos. Selvityksiä 10/98. p. 28 - 54. Teoksessa Ala - Orvola, L., Nummela, P., Mäkimattila, M. \& Ala-Mantila, O. (toim.) Ajankohtaista viljelijöiden suunnitelmista, tuotannollisesta yhteistyöstä ja tuotantokustannuksista. Helsinki: Maatalouden taloudellinen tutkimuslaitos.

Pro Agria 2005. Maidontuotannon tulokset 2004. Saatavissa http://www.proagria.fi/ajankohtaista/uutiset

Richter, T. 2005. The European organic market between strong growth and consolidation, Current state and prospects. Biofach 2005. FiBL. Saatavissa: http://www.fibl.org/aktuell/termine/2005/biofach/documents/organic-market-europe-2005_000.pdf

Seuri, P. 2002. Nutrient utilization with and without recycling within farming systems. In: Jakob Magid et al. (eds). Urban areas - rural areas and recycling - the organic way forward? DARCOF Report 3: 175-181. Saatavissa: http://www.agsci.kvl.dk/njf327/papers/NJF-Co-development.pdf

Suomen Gallup Elintarviketieto Oy 2004. Eeva Heikkilä "Luomutuotannon kehitysnäkymät - viljelijäkysely" FinfoodLuomu. Saatavissa: http://www.finfood.fi 